\begin{tabular}{|l|l|l|}
\hline \multicolumn{2}{|c|}{ PublisherInfo } \\
\hline \hline PublisherName & $:$ & BioMed Central \\
\hline \hline PublisherLocation & $:$ & London \\
\hline \hline PublisherImprintName & $:$ & BioMed Central \\
\hline \hline
\end{tabular}

\title{
US DOE presents priorities
}

\begin{tabular}{|l|l|l||}
\hline \multicolumn{2}{|c||}{ ArticleInfo } \\
\hline \hline ArticleID & $:$ & 4879 \\
\hline \hline ArticleDOI & $:$ & $10.1186 /$ gb-spotlight-20031112-01 \\
\hline \hline ArticleCitationID & $:$ & spotlight-20031112-01 \\
\hline \hline ArticleSequenceNumber & $:$ & 231 \\
\hline \hline ArticleCategory & $:$ & Research news \\
\hline ArticleFirstPage & $:$ & 1 \\
\hline \hline ArticleLastPage & $:$ & 3 \\
\hline \hline & $:$ & RegistrationDate : 2003-11-12 \\
ArticleHistory & $:$ & OnlineDate \\
\hline \hline ArticleCopyright & $:$ & BioMed Central Ltd2003-11-12 \\
\hline \hline ArticleGrants & $:$ & \\
\hline \hline ArticleContext & $:$ & 130594411 \\
\hline \hline
\end{tabular}


Eugene Russo

Email: erusso@the-scientist.com

WASHINGTON, D.C. - US Department of Energy (DOE) Secretary Spencer Abraham yesterday (November 11) announced a new list of long-range funding priorities for $28 \mathrm{DOE}$ facilities that includes several life science initiatives. The blueprint, presented at a press briefing in Washington D.C., recommends plans to update existing facilities as well as create new ones over the next 20 years.

Although most of the priorities are for projects in the physical sciences, among the top priorities are a few related to life sciences: a 'Protein Production and Tags' facility that would mass produce thousands of proteins per year and create tags to identify them; and a 'Characterization and Imaging of Molecular Machines' facility that would focus on isolating, characterizing, and creating images of molecular machines that perform cellular functions. It was the DOE that coordinated the 13-year Human Genome Project with the National Institutes of Health.

The first on the DOE 20-year wish list is ITER (which means 'the way' in Latin), an international collaboration to build the first fusion science experiment capable of producing a self-sustaining fusion reaction. The second is an 'UltraScale Scientific Computing Capability,' a multisite facility that would increase the computing capacity available to scientific research by a factor of 100 . Abraham noted that the recently constructed Japanese supercomputer, called 'Earth Simulator,' has the computing power of the 20 fastest US computers.

Other near-term priorities include a probe to study dark matter in conjunction with NASA, a powerful electron laser to enable better study of matter and chemical reactions, a rare isotope accelerator to explore new rare isotopes, and an upgrade to the Energy Sciences Network for university and industry scientists accessing DOE resources.

Midterm priorities include a facility for the analysis of modeling and cellular systems and one for whole proteome analysis, as well as an underground 'double beta decay detector' to measure neutrino mass. Far-term priorities include a next-generation national synchrotron and a fusion energy test power plant. Abraham said that the blueprint will likely be reevaluated repeatedly in the future.

The four recommended life science-related facilities are central elements of the DOE Genomes to Lifeprogram, according to Keith Hodgson, director of the Stanford Synchrotron Radiation Laboratory and chair of the DOE Biological and Environmental Research Advisory Committee. The program focuses on studying microbial and other systems to discover applications in energy production, environmental cleanup, and climate change mitigation.

All of the life science facilities on the list are already being explored in the form of pilot projects. Hodgson said that although no important life science facilities were omitted in his view, he and his committee feel that policymakers must also recognize the importance of growing the science programs and personnel that will utilize the proposed facilities. "We would hope that in the broader portfolio of coming years, programs not only sustain but increase the research base in order to make most effective use of all of these facilities," he told us.

Congress recently authorized $\$ 3.2$ billion in fiscal year 2004 for R\&D at the DOE Office of Science. It's a boost of $\$ 131$ million over the president's proposed budget, but still represents an increase that's 
barely above inflation, keeping Office of Science funding flat for the fourth year in a row, according to a report by the American Association for the Advancement of Science.

When addressing the audience's questions, and in follow-up comments to us, Secretary Abraham declined to speculate as to whether Congress and the president (as well as the next 2 decades' future presidents and congresses) are likely to fund the centers in full. Nor did he speculate as to the budget increases that would be necessary in the short term in order to fund some or all of the recommended centers. "We'd like to see all 28 funded," he said. "But maybe in the end it will be just a few."

Michelle Buchanan, director of the Center for Molecular and Cellular Systems at the Oak Ridge National Laboratory and the principal investigator of a Genomes to Life research awardinvolving the high-throughput identification and characterization of protein complexes, noted that facility projects in recent years were also initially the product of a vision that didn't have financial backing. In the 1980s, Al Trivelpiece, then the director of the DOE's Office of Science, a position now held by Raymond Orbach, proposed synchrotrons and neutron sources like the Spallation Neutron Source at Oak Ridge, which is slated for completion in 2006. Neutrons are excellent for scrutinizing organic and biological molecules.

"As a scientist, I find it very exciting because in many cases these facilities have really revolutionized science," she said. Buchanan said she looks forward to the protein production and molecular machine facilities, which she hopes will provide high-quality protein data and the sort of rigorous data standards that gene sequencers have become accustomed to.

\section{References}

1. Facilities for the future of science: A twenty-year outlook, Department of Energy Office of Science report, November 2003., [http://www.sc.doe.gov/Sub/Facilities_for_future/20-Year-Outlook-screen.pdf]

2. ITER, [http://www.iter.org/]

3. Genomes to Life, [http://www.doegenomestolife.org/index.shtml]

4. DOE receives $\$ 8.8$ billion for $\mathrm{R} \& \mathrm{D}$, modest increase for science programs, American Association for the Advancement of Science Research and Development Funding update, November 10, 2003. [http://www .aaas.org/spp/rd/doe04c.htm]

5. Russo E: Genomes to Life grants awarded Genome Biology, July 30, 2002., [http://genomebiology.com/researchnews/default.asp?arx_id=gb-spotlight-20020730-01]

This PDF file was created after publication. 